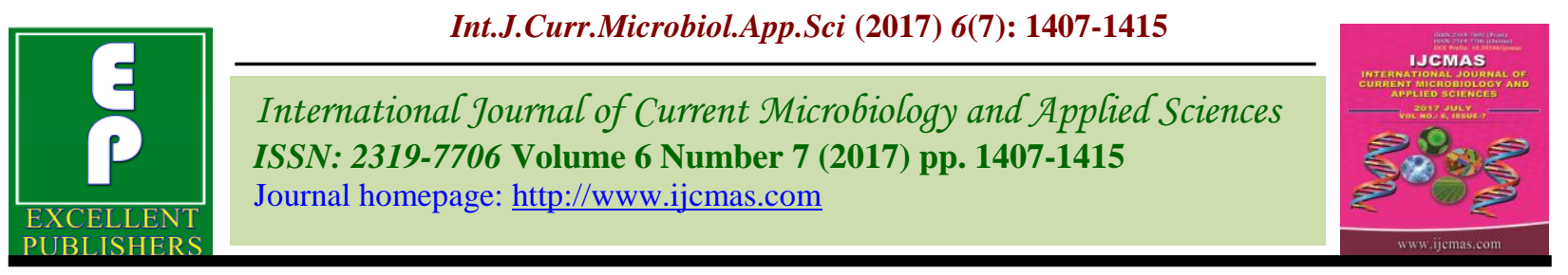

Original Research Article

https://doi.org/10.20546/ijcmas.2017.607.168

\title{
Effect of Integrated Nutrient Management Practices Effect on Carbon Sequestration, Carbon Stock, Plant Growth Parameters and Economics of Cauliflower
}

\author{
Laxmi Kashyap, Challa Venu Reddy* and Alok Tiwari
}

Indira Gandhi Krishi Vishwa Vidhyalaya, Raipur, Chattishgarh, India

*Corresponding author

\begin{tabular}{|c|c|}
\hline & A B S T R A C T \\
\hline & The experiment sight was carried out in the Research farm of Indira Gandhi Krishi \\
\hline Keywords & Central part of Chhattisgarh. The notable improvement with respect to growth \\
\hline $\begin{array}{l}\text { Vermicompost, } \\
\text { Inorganic } \\
\text { fertilizers, Benefit } \\
\text { cost ratio, } \\
\text { Photosynthates. }\end{array}$ & $\begin{array}{l}\text { parameters with the use of Vermicompost-A and inorganic fertilizers may be } \\
\text { attributed due to sufficient availability of nitrogen, phosphorus, potassium and } \\
\text { other essential nutrients which resulted in increasing growth parameters. The } \\
\text { highest benefit cost ratio was recorded under } 100 \% \text { Recommended dose of } \\
\text { fertilizer (6.39) treatment and lowest value } 40 \text { recorded in } 25 \% \text { RDF+ V-C (2.55). }\end{array}$ \\
\hline Article Info & Combined use of organic and inorganic fertilizer was efficient in yield increases \\
\hline $\begin{array}{l}\text { Accepted: } \\
\text { 17 June } 2017 \\
\text { Available Online: } \\
10 \text { July } 2017\end{array}$ & $\begin{array}{l}\text { increases in uptake of nutrients and translocation of photosynthates from sources } \\
\text { yard manure produced higher yields and reduces the rate of Soil Organic Carbon }\end{array}$ \\
\hline & $\begin{array}{l}\text { depletion. The magnitude of SOC buildup was proportional to the organic } \\
\text { amendments. }\end{array}$ \\
\hline
\end{tabular}

\section{Introduction}

Cauliflower (Brassica oleracea L. var botrytis) is one of the most important vegetable crops grown throughout the world. It removes large quantity of major nutrients from the soil. As such judicious application of fertilizers is needed to meet out the nutritional requirement of the crops. Heavy manuring has been recommended for getting good yields of Cauliflower by different workers in India. However continuous application of huge amount of chemical fertilizers hampers the soil health and generates pollution. Also, energy resulted into high price index of chemical fertilizers coupled with their limited production. The integrated nutrient management paves the way to overcome these problems, which involves conjunctive use of chemical fertilizers and organic manures to sustain crop production and maintenance of soil health. In Soil biodiversity, especially earthworms play important role in carbon dynamics and store in soil (Madhab et al., 2013). However, biofertilizers offer an alternative to chemical inputs, which have an ability of mobilizing the nutritionally 
important elements from non-useable to Useable form through chemical processes and are known to increase yield in several vegetables. The use of biofertilizers in combination with chemical fertilizers and organic manures offer a great opportunity to increase the production of cauliflower with less cost. Substitution of organic manures and amendments (biofertilizers and biocontrol agents) and green manures combinations significantly enhanced growth, flowering, yield, important quality attributes and postharvest life of banana compared to either organic manure alone or inorganic sources alone (vanilarasu et al., 2014).

Soil organic carbon (SOC) sequestration contributes to the mitigation of greenhouse gas emissions and to the improvement of soil fertility (Lal, 2004). Net SOC sequestration is the balance of organic $\mathrm{C}$ inputs into the soil (via crop residues, organic amendments in compost, animal manure, etc.) and organic $\mathrm{C}$ decomposition by soil microbes. SOC sequestration efficiency is commonly expressed by the relationship between annual $\mathrm{C}$ input and SOC accumulation rate, which is an indicator of soil $\mathrm{C}$ sequestration ability [McLauchlan, 2006]. Therefore, information about the $\mathrm{C}$ sequestration efficiency is useful for seeking high efficiency management strategies of enhancing the SOC stock and soil fertility.

\section{Materials and Methods}

The present investigation was carried out in the research farm of Indira Gandhi Krishi Vishwavidyalaya, Raipur during rabi season 2013- 2014.

The materials used and methodology adopted in the investigation are described below. Raipur is situated in the central part of Chhattisgarh, agro-climatologically known as "Chhattisgarh Plains" and lies between $21^{0}$ 16 'N Latitude and $81^{\circ} 36^{\prime} \mathrm{E}$ Longitude with an altitude of $289.56 \mathrm{~m}$ above the mean sea level.

\section{Growth and development}

\section{Plant height}

Five randomly selected plants from each plot were tagged for recording observations. Plant heights from ground level up to the top of the tallest leaf were measured at 20, 40 and 60 days after transplanting

\section{Stalk length}

Stalk length was measured from the base of the head to the tip of the root of the observed plant after harvesting and then the average value was calculated.

\section{Plant spread}

Five plants were selected randomly in each treatments and plant spread was measured by using meter tape.

\section{Root length}

The length of root taken from ground level to the tip of root measured with the help of metre scale after harvest of crop.

\section{Yield parameters}

\section{Gross weight}

The gross weight of five tagged plants was recorded at the time of harvesting and finally the average was calculated for tabulation of yield.

\section{Net weight}

The net weight of five tagged plants was recorded at the time of harvesting and then the average net weight was calculated. The plants were harvested and then the stalk and 
leaves were removed and then after net weight was noted.

\section{Gross yield}

The plants were harvested at the proper stage and their individual gross weight was taken. Thus the gross yield of each treatment was noted and expressed in tonnes per hectare.

\section{Net yield}

The plants were harvested, stalk was cutted and non-wrapper leaves were removed and the net weight was taken. Thus the net yield of each treatment was noted and was expressed in tonnes per hectare.

\section{Economics}

Cost of cultivation for each treatment was worked out separately (Appendix - II). Gross return (Rs. /ha) was obtained by converting the harvest in to monetary terms at the prevailing market rate during the course of investigation.

Net return was obtained by deducting cost of cultivation from gross return. The benefit: cost ratio was calculated with the help of following formula (Reddy et al., 2004):

Benefit Cost Ratio = Net returns (Rs)/ Total Cost of Cultivation (Rs)

\section{Calculation of SOC Stock and SOC sequestration rate}

Soil Organic Carbon (SOC) Stock (ton/ha) in top soil was calculated using the equation:

SOC Stock $=$ SOC $\times$ BD $\times$ Depth of soil sample

Where, SOC was in percentage, Bulk Density in $\mathrm{Mg} / \mathrm{m}^{3}$ and Depth in centimeters $(\mathrm{Cm})$.
SOC Sequestration rate (SSR, ton/ha/yr) was estimated for the top soil by following equation

$\mathrm{SSR}=[\mathrm{SOC}$ stock (final) - SOC Stock (initial) $] / t$

Where

$\mathrm{t}$ is duration of experiment in years.

\section{Results and Discussion}

\section{Effect of different treatments on growth and yield of cauliflower}

The growth contributing characters were recorded for the following variables namely plant height, stalk length, plant spread and root length.

\section{Plant height}

The data recorded on height of plant at different growth stages are presented in the table 2 .

The plant height was recorded maximum under $50 \%$ RDF+V-A (53.29), followed by $25 \% \mathrm{RDF}+\mathrm{V}-\mathrm{A}(48.98 \mathrm{~cm})$ and minimum height was recorded in control $(20.08 \mathrm{~cm})$.

The notable improvement with respect to growth parameters with the use of vermicompost-A and inorganic fertilizers may be attributed due to sufficient availability of nitrogen, phosphorus, potassium and others essential nutrients which resulted in increasing growth parameters.

The results were in agreement with the findings of Alam (2006) and Azad (2000), who stated that combined application of manures and chemical fertilizers performed the highest plant height of cabbage. 
Bonkyoon (2004) reported that the plant height of potato was higher in the plots where earthworm casts (vermicompost) and NPK fertilizers were applied than in the control plot.

\section{Stalk length}

The effect of integrated nutrient management practices on stalk length was statistically significant. Application of $50 \% \mathrm{RDF}+\mathrm{V}-\mathrm{A}$ vermicompost significantly increased the stalk length (Table 2) during the growth period of cauliflower. 38 The maximum stalk length was recorded in $50 \% \mathrm{RDF}+\mathrm{V}$-A $(21.32 \mathrm{~cm}), 25 \% \mathrm{RDF}+\mathrm{V}-\mathrm{A}(20.44 \mathrm{~cm})$ followed by $50 \% \mathrm{RDF}+\mathrm{V}-\mathrm{B}(19.88 \mathrm{~cm})$ and minimum values were recorded in control $(12.66 \mathrm{~cm})$.
The stalk length was increased significantly due to the application of different sources of vermicomposts and inorganic fertilizers alone or their combinations (Table 1). This might be due to the better soil environment as compared to control. The findings were in close conformity with the findings of Singh et al., (2009), Singh et al., (2006) and Kalyani et al., (1996).

\section{Plant spread}

The data presented in table 2 revealed that the effect of different integrated nutrient management practices on plant spread was statistically significant. Application of $50 \%$ $\mathrm{RDF}+\mathrm{V}$-A vermicompost recorded maximum plant spread $(186.9 \mathrm{~cm})$ followed by $50 \%$ $\mathrm{RDF}+\mathrm{V}-\mathrm{B}(173.2 \mathrm{~cm})$ and lowest values were recorded in control $(143 \mathrm{~cm})$.

Table.1 Compositions of different sources of vermicompost

\begin{tabular}{|l|l|l|l|}
\hline Nutrient Content & V-A & V-B & V-C \\
\hline Nitrogen (\%) & 2.55 & 2.44 & 2.38 \\
\hline Phosphorus (\%) & 1.77 & 1.27 & 1.47 \\
\hline Potassium (\%) & 1.95 & 1.85 & 1.56 \\
\hline
\end{tabular}

Table.2 Effect of integrated nutrient management on Plant growth parameters and yield of cauliflower

\begin{tabular}{|l|c|c|c|c|}
\hline Treatments & $\begin{array}{c}\text { Plant Height } \\
(\mathrm{cm})\end{array}$ & $\begin{array}{c}\text { Stalk Length } \\
(\mathrm{cm})\end{array}$ & $\begin{array}{c}\text { Plant Spread } \\
(\mathrm{cm})\end{array}$ & $\begin{array}{c}\text { Length of } \\
\text { root }(\mathrm{cm})\end{array}$ \\
\hline Control & 20.08 & 12.66 & 143 & 7.72 \\
\hline $25 \%$ RDF+ V-A & 48.98 & 20.44 & 147.8 & 10.82 \\
\hline $25 \%$ RDF+V-B & 45.22 & 18.56 & 145.6 & 10.32 \\
\hline $25 \%$ RDF+V-C & 44.19 & 18.48 & 144.1 & 7.32 \\
\hline $50 \%$ RDF+V-A & 53.29 & 21.32 & 186.9 & 12.52 \\
\hline $50 \%$ RDF+V-B & 50.44 & 19.88 & 173.2 & 10.94 \\
\hline $50 \%$ RDF+V-C & 46.44 & 19.30 & 144.1 & 10.81 \\
\hline $100 \%$ RDF & 48.34 & 19.26 & 167.4 & 9.66 \\
\hline SEm $( \pm)$ & 2.358 & 0.51 & 10.11 & 0.192 \\
\hline CD $(\mathrm{p}=0.05)$ & 7.154 & 1.56 & 30.67 & 0.583 \\
\hline
\end{tabular}


Table.3 Effect of different treatments on benefit: cost ratio of cauliflower

\begin{tabular}{|l|c|c|c|c|c|}
\hline \multicolumn{1}{|c|}{ Treatments } & $\begin{array}{c}\text { Cost of } \\
\text { cultivation } \\
\text { (a) }\end{array}$ & $\begin{array}{c}\text { Yield } \\
\text { (t/ha) }\end{array}$ & $\begin{array}{c}\text { Gross return } \\
\text { (b)=avg } \\
\text { yield } \times \text { price }\end{array}$ & $\begin{array}{c}\text { Net return } \\
=(\mathrm{b}-\mathrm{a})\end{array}$ & $\begin{array}{c}\text { Benefit: cost } \\
\text { Ratio }\end{array}$ \\
\hline Control & 32672 & 13 & $1,30,000$ & 97328 & 2.97 \\
\hline 25\% RDF + V-A & 61814.46 & 24 & $2,40,000$ & 178185.54 & 2.88 \\
\hline 25\% RDF + V-B & 61814.46 & 23 & $2,30,000$ & 168185.54 & 2.72 \\
\hline 25\% RDF + V-C & 61814.46 & 22 & $2,20,000$ & 158185.54 & 2.55 \\
\hline 50\% RDF +V-A & 63843.83 & 33 & $3,30,000$ & 266156.17 & 4.16 \\
\hline $50 \%$ RDF +V-B & 63843.83 & 31 & $3,10,000$ & 246156.17 & 3.85 \\
\hline $50 \%$ RDF +V-C & 63843.83 & 29 & $2,90,000$ & 226156.17 & 3.54 \\
\hline $100 \%$ RDF & 43290.02 & 32 & $3,20,000$ & 276709.98 & 6.93 \\
\hline
\end{tabular}

Table.4 Effect of various sources of vermicompost and different doses of fertilizers on SOC stock, SOC sequestration and \% carbon buildup over control

\begin{tabular}{|c|c|c|c|c|c|}
\hline Treatments & $\begin{array}{c}\mathrm{OC} \\
(\%)\end{array}$ & $\mathrm{B} . \mathrm{D}\left(\mathrm{Mg} / \mathrm{m}^{3}\right)$ & $\begin{array}{c}\text { SOC } \\
\text { Stock }\end{array}$ & $\begin{array}{c}\text { Carbon Sequestration } \\
\text { Rate }\end{array}$ & $\begin{array}{c}\text { \% Carbon change } \\
\text { over control }\end{array}$ \\
\hline Initial & 0.55 & 1.45 & 11.96 & -- & -- \\
\hline Control & 0.55 & 1.44 & 11.88 & -0.0825 & -- \\
\hline 25\% RDF+V-A & 0.61 & 1.35 & 12.35 & 0.39 & 3.83 \\
\hline 25\% RDF+V-B & 0.59 & 1.38 & 12.21 & 0.2505 & 2.73 \\
\hline 25\% RDF+V-C & 0.59 & 1.4 & 12.39 & 0.4275 & 4.12 \\
\hline $50 \%$ RDF+V-A & 0.63 & 1.33 & 12.57 & 0.606 & 5.48 \\
\hline $50 \%$ RDF+V-B & 0.6 & 1.34 & 12.06 & 0.0975 & 1.49 \\
\hline $50 \%$ RDF+V-C & 0.6 & 1.33 & 11.97 & 0.0075 & 0.75 \\
\hline $100 \%$ RDF & 0.61 & 1.4 & 12.81 & 0.8475 & 7.26 \\
\hline
\end{tabular}

Fig.1 Influence of organic carbon (\%) on mean weight diameter

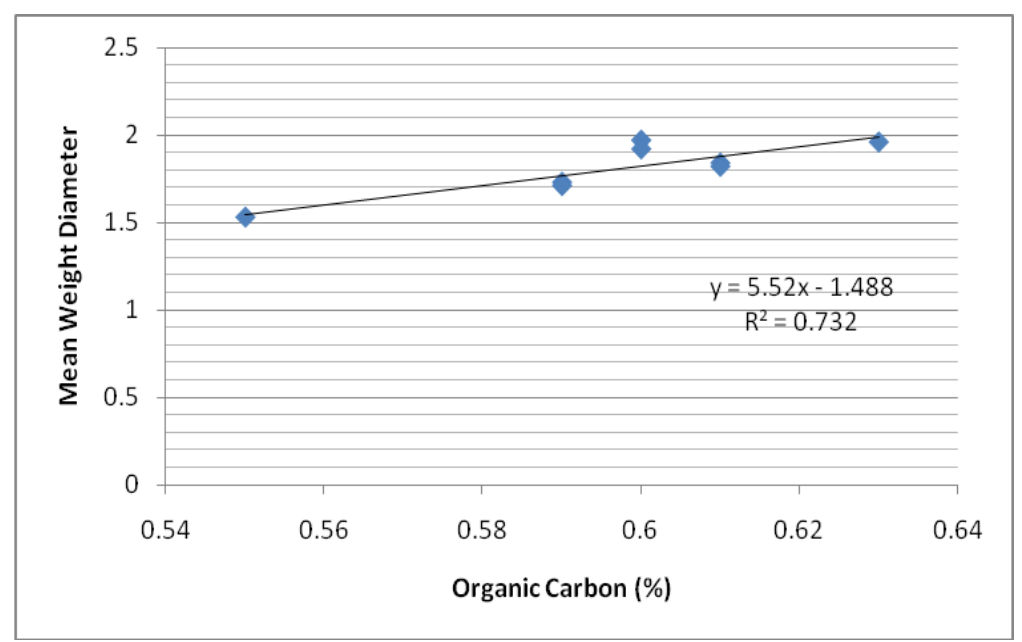


Fig.2 Influence of SOC stock on yield of cauliflower

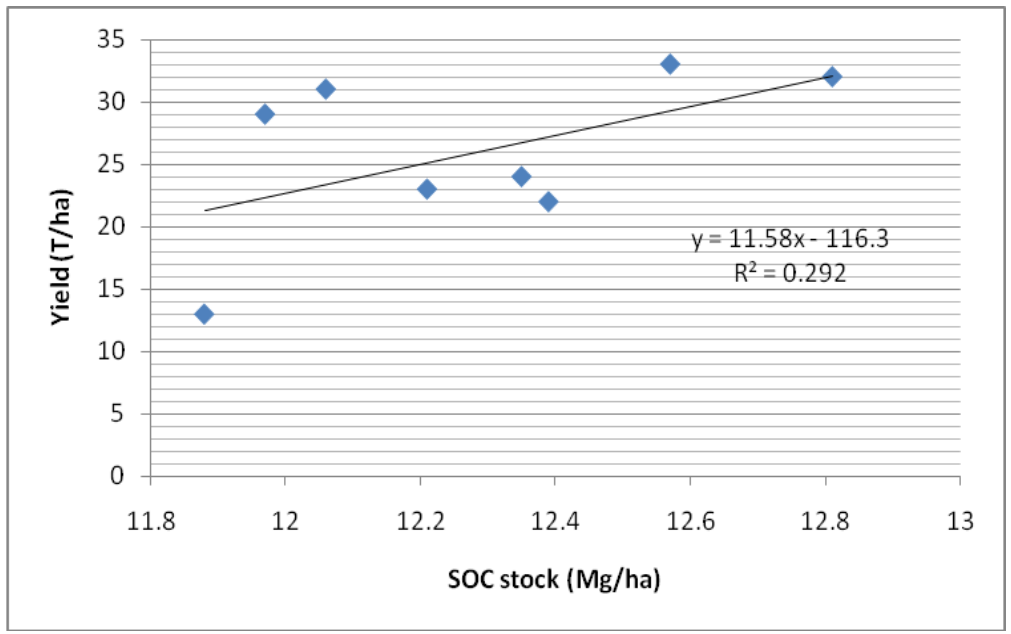

Fig.3 Influence of organic carbon (\%) on carbon sequestration rate

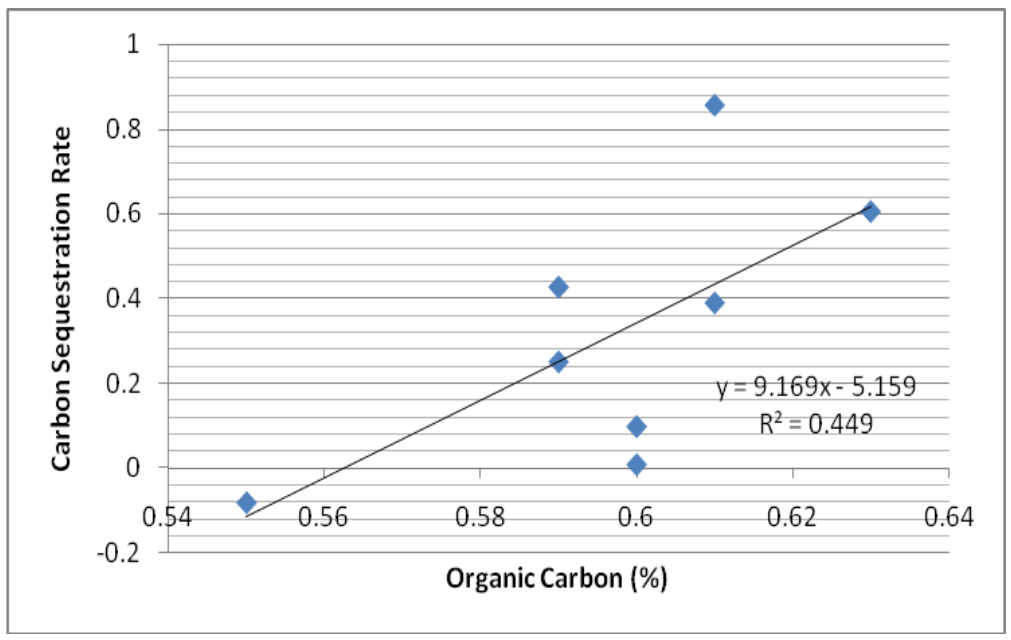

Fig.4 Effect of different sources of vermicompost and different recommended doses of fertilizers on benefit-cost ratio

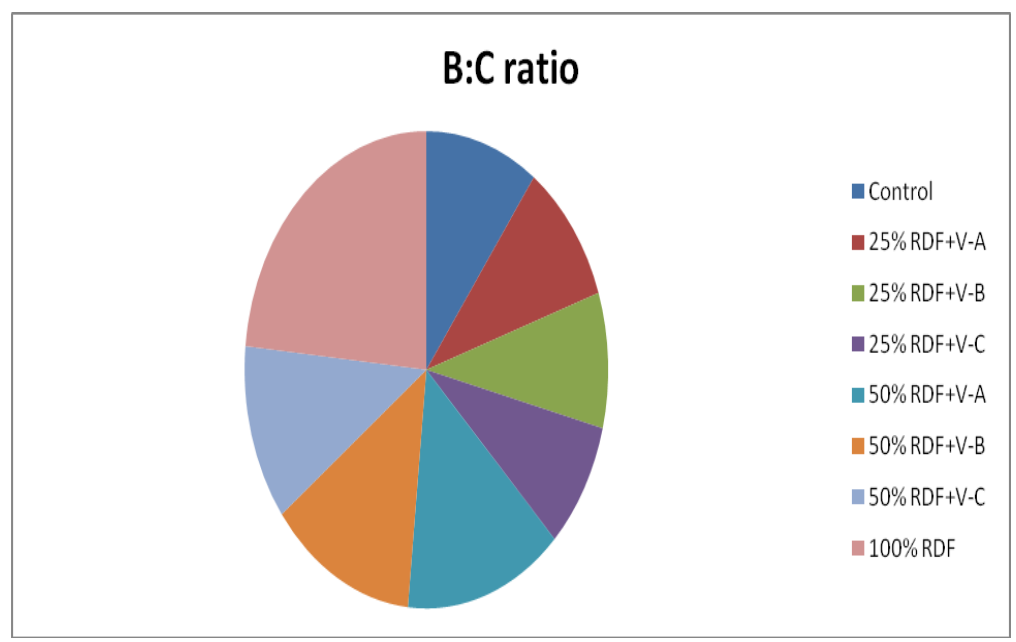


Fig.5 Impact of different doses of fertilizer and different sources of vermicompost on yield of cauliflower

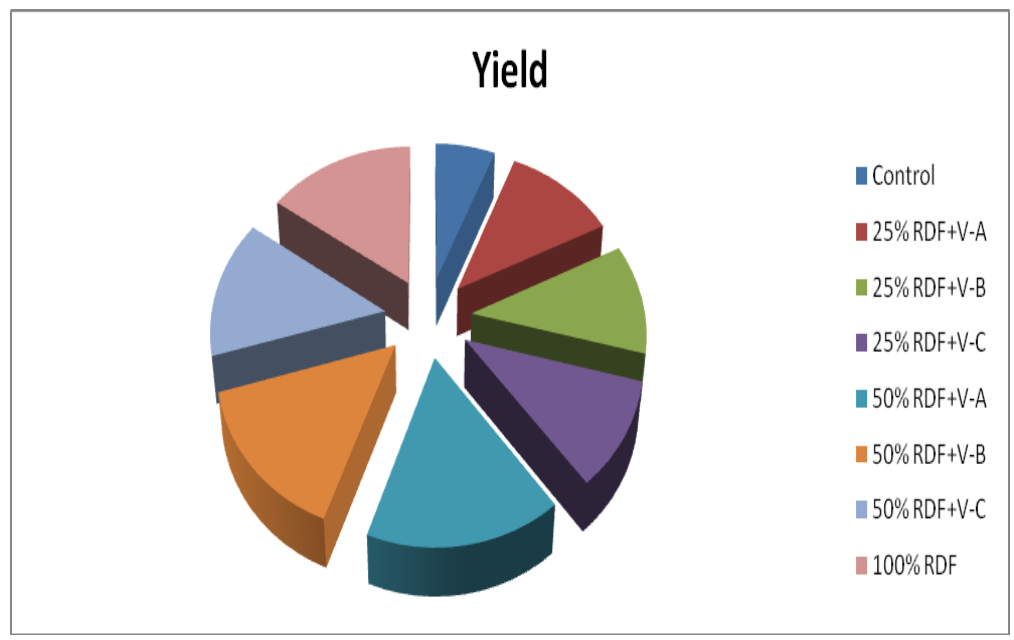

\section{Root length}

The influence of vermicompost along with chemical fertilizers significantly increased the root length as compared to omission of fertilizer (Table 2) i.e. absolute control. The highest value was observed in 50\% NPK + VA treated vermicompost plot $(12.52 \mathrm{~cm})$, followed by $50 \% \mathrm{RDF}+\mathrm{V}-\mathrm{B}(10.94 \mathrm{~cm})$ and lowest values were recorded in control (7.72 $\mathrm{cm})$.

\section{Carbon stock, carbon sequestration rate, percent carbon buildup}

The Soil Organic carbon stock and Carbon sequestration Rate values are higher recorded in $100 \% \mathrm{RDF}(12.81,0.85)$ followed by $50 \%$ $\mathrm{RDF}+\mathrm{V}-\mathrm{A}(12.57,0.61)$ and the lower values were recorded in Control (11.96, -0.0825) treatments. West and six (2007) reported that the duration of Carbon sequestration varies between ecosystem, climate regimes and fertilization management (e.g. Soil organic amendment inputs). A significant relation was also observed between Organic Carbon (\%) and Mean weight Diameter $\left(\mathrm{R}^{2}=0.732\right)$ (Fig. 1), SOC stock and Yield $\left(\mathrm{R}^{2}=0.292\right)$ (Fig. 2) and Organic carbon (\%) and Carbon Sequestration Rate $\left(\mathrm{R}^{2}=0.449\right)$ (Fig. 3). Thus, the maintenance of soil organic carbon through regular addition of organic determines the sustainability of soil moisture. Increase in SOC stock also enhances water holding capacity of the soil (Du et al., 2009) that mitigates intermittent droughts (Table 4). The Percent Carbon buildup over control is higher in fully inorganic treatment (7.26) followed by $50 \%$ inorganic and $50 \%$ vermicompost (source-A) treatment (5.48) and the lower values were recorded in 50\% inorganic and 50\% vermicompost (source-B) treatment (0.75). In accordance with the observations, there is a strong relationship between the Yield and SOC percentage/stock (Singh et al., 2004). It is a linear relationship between the yield and SOC. These trends indicate the importance of these fractions of SOC on crop yield through improvement in soil health (Table 4, Fig. 3).

\section{Economics}

The adoption of any technology in modern agriculture can only be feasible and acceptable to farmers if it is economically viable. In the present investigation the highest cost of cultivation (Rs 63843.83 /ha) was worked out under the treatments $50 \% \mathrm{RDF}+$ Vermicompost (A, B and C) (Table 3). 
Maximum gross returns (Rs 3,30,000/ha),net return (Rs.2,66,156.17 /ha) were recorded under $50 \% \mathrm{RDF}+\mathrm{V}$-A treatments, however, the lowest value of these parameters were recorded under control treatments. The highest benefit: cost ratio was recorded under $100 \%$ RDF (6.39) treatments and lowest value 40 recorded in $25 \% \mathrm{RDF}+\mathrm{V}-\mathrm{C}$ (2.55). The highest benefit: cost ratio may be due to higher yield potential of $100 \%$ NPK treatments (Fig. 4) (Table 3).

Integrated nutrient management including vermicompost and recommended dose of fertilizers showed its best results with respect to plant growth parameters and yield of cauliflower (Fig. 5). The adoption of any technology in modern agriculture can only be feasible and acceptable to farmers if it is economically viable. In the present investigation the highest cost of cultivation (Rs 63,843.83/ha) was worked out under the treatments $50 \%$ RDF along with different sources of vermicompost (A, B and C). Maximum gross returns (Rs 3,30,000/ha), net return (Rs.2,66,156.17 /ha) were recorded under $50 \%$ RDF + V-A treatments, However, the lowest value of these parameters was recorded under control treatments. The values under $50 \% \mathrm{RDF}+\mathrm{V}-\mathrm{A}$ and $100 \% \mathrm{RDF}$ were 33 t/ha and 32 t/ha respectively. Combined use of organic and inorganic fertilizer was efficient in yield increases over the exclusive application of chemical fertilizers and can be attributed to increases in uptake and translocation of photosynthates from sources (leaves) to sink (curd). The highest benefit: cost ratio was recorded under $100 \%$ RDF (6:39) treatments and lowest value recorded in $25 \% \mathrm{RDF}+\mathrm{V}-\mathrm{C}$ (2.55). Improvement in Soil Organic Stock, Carbon Sequestration rate and percent carbon change over control by application of vermicompost also improved nutrient uptake of macro and micro nutrients significantly in all treatments compared to non-treated control treatments. It can be concluded that balanced application of NPK fertilizers with vermicompost was best option for higher crop yields.

\section{References}

Alam. M.N., Jahan. M.S. Ali. M.K., Islam. M.S. and Khandaker. S.M.A.T. 2007. Effect of vermicompost and NPKS Fertilizers on Growth, Yield and Yield components of Red Amarnath. Aust. J. Basic \& Appl. Sci. 1(4): 706-716.

Bongkyoon, K. 2004. Effect of vermicompost on growth of fall - cropping potato in volcanic ash soil. Korean J. Crop. Sci. Korean J. Crop. Sci. 49(4): 305-308.

Du Z, Liu S, Li K, Ren T.2009. Soil Organic carbon and physical quality as influenced by long term application of residue and mineral fertilizer in the North China Plain. Australian Journal of Soil Research 47:585-591.

Kalyani, D.P., Sankar, C.R. and Prasad, D. 1996. Studies on the effect of nitrogen and azospirillum on growth and yield of cauliflower. South Indian Hort. 44(5-6): 147-149.

Lal R (2004) Soil carbon sequestration impacts on global climate change and food security. Science 304: 1623-1627.

Madhab chandradash and Niranjan behra 2013. Carbon sequestration and role of earthworms in Indian land uses: A Review. The Ecoscan 7(1\&2):1-7.

McLauchlan KK (2006). Effects of soil texture on soil carbon and nitrogen dynamics after cessation of agriculture, Geoderma 136: 289-299.

Singh, A., Singh, T. and Singh, B.N. 2009. Influence of integrated nutrient management on growth, yield and Economics of cauliflower. (Brassica oleracea L. Var. Botrytis) Veg. Sci. 36 (3): 340-343.

Singh MV, Wanjari RH, Adhikari T.2004. 
Nutrient Dynamics, Crop productivity, and Sustainability under Long term Fertilizer experiments in India. All India Coordinated Research project on LongTerm Fertility Experiment, Indian Institute of Soil Science, Bhopal: 120.

Singh, P., Singh, R.P. and Singh, K.P. 2006. Integrated effect of bio inoculants, Organic and inorganic fertilizer on growth and yield of cabbage. Crop Res. 32(2): 188-191.

Vanilarasu et.al. 2014. Influence of organic manures and amendments on growth, flowering, yield, quality and postharvest life of Banana cv. Grand Naine. The Ecoscan special issues vol.6:147152.

West To, Six J (2007) considering the influence of sequestration duration and carbon saturation on estimates of soil carbon capacity. Climate Change 80:2541.

\section{How to cite this article:}

Laxmi Kashyap, Challa Venu Reddy and Alok Tiwari. 2017. Effect of Integrated Nutrient Management Practices Effect on Carbon Sequestration, Carbon Stock, Plant Growth Parameters and Economics of Cauliflower. Int.J.Curr.Microbiol.App.Sci. 6(7): 1407-1415. doi: https://doi.org/10.20546/ijcmas.2017.607.168 